\title{
Paclobutrazol and Its Use in Fruit Production: A Review
}

\section{Laura Raquel Orozco-Meléndez ${ }^{1}$, Ofelia Adriana Hernández-Rodríguez ${ }^{1}$, Oscar Cruz-Álvarez ${ }^{1}$, Loreto Robles-Hernández ${ }^{1}$, Graciela Dolores Ávila-Quezada ${ }^{1}$, Esteban Sánchez Chavez ${ }^{2}$, Damián Aarón Porras-Flores ${ }^{1}$ and Dámaris Leopoldina Ojeda-Barrios ${ }^{1, *}$}

\author{
${ }^{1}$ Facultad de Ciencias Agrotecnológicas, Universidad Autónoma de Chihuahua, Avenida Pascual Orozco, Chihuahua, 31350, México \\ ${ }^{2}$ Centro de Investigación y Desarrollo A.C., Delicias, Chihuahua, 33089, México \\ ${ }^{*}$ Corresponding Author: Dámaris Leopoldina Ojeda-Barrios. Email: dojeda@uach.mx
}

Received: 08 April 2021 Accepted: 24 June 2021

\begin{abstract}
There are documentary records referring to paclobutrazol (PBZ) as a growth bioregulator that inhibits the gibberellin synthesis and its application increases yields in fruit and vegetable crop productions. Its agronomic management includes it as an emerging technology to reduce vigour, promote flower induction and flower development in fruit trees with increased economic returns. Its use is banned in some countries because of concerns about residues that can cause harmful effects on the environment. Therefore, the aim of this article was to collect, analyse and summarise relevant information on the use of PBZ in fruit tree production and its possible risks to the environment. The results obtained indicated that the application of PBZ can be effective in solving some problems related to flowering if it is applied in the right amount and at the right time. However, it is necessary to elucidate the physiological processes with which it is associated and its response to be taken into account to increase yield. PBZ is currently used in fruit trees such as mango, lime, apple and guava, increasing their productivity. However, some studies have shown its residual effect on the environment. Therefore, PBZ is a viable strategy, because it presents a series of advantages in the production of fruit trees. However, it is vital to generate protocols that seek its regulation with a rational and sustainable approach.
\end{abstract}

\section{KEYWORDS}

Environment; flower induction; gibberellin biosynthesis; growth bioregulator; vegetative growth

\section{Introduction}

Globally, agriculture is one of the most important economic activities, given its contribution to food production [1]. Population growth has a direct impact on the need to increase crop yields, and consumers expect high quality, nutritious, clean, healthy and safe products [2]. The integration of emerging technologies in the different production systems must be in an environment of safety and sustainability [1]. Therefore, the Food and Agriculture Organization of the United Nations (FAO) coined the concept of food security as "physical and economic access to sufficient, safe and nutritious food to meet one's dietary needs and food preferences for an active and healthy life" [3].

The application of nutrients and growth bioregulators increases crop productivity [2]. The latter can be classified according to the physiological processes with which they are associated and their response to 
application [4]. Previous reports indicate that low concentrations of these compounds facilitate agronomic management, and their effect can be linked to inhibition, slowing and induction of sprouting, flowering and fruit ripening [5]. Among these growth bioregulators is paclobutrazol (PBZ) (growth inhibitor) [6-8], which reduces vigour, and promotes flower induction and development $[9,10]$.

In the last decade, among the common agronomic management practices for fruit tree production is the use of PBZ, which promotes various effects. For example, in India it is used to increase fruit quality in litchi (Litchi chinensis Sonn) "China" by inhibiting vegetative growth [11], pear "Clapp's" (Pyrus pyrifolia L.) [12] and Indian walnut "Ullal-3" (Anacardium occidentale L.) [9]. In China, it is used to reduce vegetative growth in the cultivation of "Western Schley" and "Mahan" pecan [Carya illinoinensis (Wang.) K. Koch] [13,14]. In Brazil, it is used to increase the size and shape of the fruit of the "Hass" avocado (Persea americana L.) [15].

In Mexico it is used to promote flowering and increase production in guava (Psidium guajaba L.) "Calvillo", "Hidrosac" and "Caxcana" [16], and in mango (Mangifera indica L.) "Tommy Atkins" [17] "Ataulfo" and "Manila" [18,19].

The use of PBZ contributes to increase production value (yield and fruit quality), however, there is evidence of its residual effects and its negative effect on consumers' health [20]. In addition, there is information that it can cause environmental pollution (groundwater and soil) [21]. The aim of this paper was to collect, analyse and summarise information on the use of PBZ in the production of some economically important fruit trees and their possible risks to the environment.

\section{Growth Bioregulators}

Among the production costs associated with the application of products to improve and increase the yield and quality of harvested fruit, the application of growth bioregulators constitute a minimal portion [5]. However, in recent years, their application has increased due to the fact that they help to improve the productivity of fruit trees.

Plants synthesise various compounds, including growth bioregulators, which promote and regulate their physiological processes (vegetative growth, flower induction, fruit set and fruit size increase) [7,22,23]. In addition, they influence the response to biotic and abiotic stresses [24]. Traditional bioregulators include auxins, gibberellins, cytokinins, and abscisic acid [25]. Research also considers brassinosteroids, salicylic acid, triazoles, jasmonates, polyamines and recently strigolactones as bioregulators [24,26,27].

Growth bioregulators can be classified according to their mode of action (Tab. 1). It is reported that they can enhance plant defence mechanisms, promote cell division and growth, processes that help to increase yield and quality fruit [28]. They can also delay or inhibit growth [8]. They also play an important role in responses to stress and adaptation such as to water deficit, high temperatures, salinity and flooding [23].

Table 1: Classification and mode of action of growth bioregulators

\begin{tabular}{llll}
\hline Classification & Examples & Mode of action & References \\
\hline Auxin & $\begin{array}{l}\text { Indoleacetic Acid, Indole } \\
\text { Butyric Acid, and } \\
\text { Naphthaleneacetic Acid }\end{array}$ & $\begin{array}{l}\text { Controls cell division, cell expansion (by } \\
\text { forming cellulose), apical dominance, } \\
\text { tropisms, stem elongation, root formation } \\
\text { and development. }\end{array}$ \\
& Gibberelic Acid & $\begin{array}{l}\text { Control fruit development (promotes cell } \\
\text { division and cell expansion), seed } \\
\text { Gibberellins }\end{array}$ & {$[29,30]$.} \\
& & germination, stem elongation, flowering and \\
& & \\
& &
\end{tabular}




\begin{tabular}{|c|c|c|c|}
\hline Classification & Examples & Mode of action & References \\
\hline Cytokinins & $\begin{array}{l}\text { Indoleacetic Acid, Indole } \\
\text { Butyric Acid, and } \\
\text { Naphthaleneacetic Acid }\end{array}$ & $\begin{array}{l}\text { Promote cell division, sprouting and root } \\
\text { development, seed and fruit development, } \\
\text { germination, senescence and response to } \\
\text { environmental stresses. }\end{array}$ & {$[31]$} \\
\hline Abscisic acid & Abscisic acid & $\begin{array}{l}\text { Induces embryo ripening, seed dormancy, } \\
\text { vegetative growth and processes related to } \\
\text { stress tolerance (stomata closure), ripening } \\
\text { and fruit abscission }\end{array}$ & {$[24]$} \\
\hline Ethylene & Ethylene & $\begin{array}{l}\text { Diminishes stem and root growth. Helps } \\
\text { flower development, fruit ripening, in } \\
\text { addition to leaf and flower senescence and } \\
\text { fruit abscission. }\end{array}$ & {$[26]$} \\
\hline Silicates & Salicylic acid & $\begin{array}{l}\text { Induces flowering, inhibits ethylene } \\
\text { biosynthesis and increases growth. Enables } \\
\text { stress regulation and stress response. }\end{array}$ & {$[24,26]$} \\
\hline Jasmonates & $\begin{array}{l}\text { Jasmonic Acid, and } \\
\text { Isojasmonic Acid }\end{array}$ & $\begin{array}{l}\text { Helps signalling in plants to respond to } \\
\text { biotic and abiotic stress. Promotes seed } \\
\text { germination, root growth and flowering. }\end{array}$ & {$[24,26]$} \\
\hline Brassinosteroids & $\begin{array}{l}\text { Brasinolide, Dolicolide and } \\
\text { Epibrasinolide }\end{array}$ & $\begin{array}{l}\text { Influence germination, rhizogenesis, } \\
\text { flowering, senescence, abscission and } \\
\text { ripening processes. They also confer } \\
\text { resistance to plants against abiotic and biotic } \\
\text { stresses. }\end{array}$ & {$[26,32]$} \\
\hline Polyamines & $\begin{array}{l}\text { Putrescine, Spermidine and } \\
\text { Spermine }\end{array}$ & $\begin{array}{l}\text { Are involved in cell division and cell } \\
\text { elongation, nucleic acid packaging, DNA } \\
\text { replication and rooting. }\end{array}$ & {$[27]$} \\
\hline Strigolactones & $\begin{array}{l}\text { Strigol, Strigyl Acetate and } \\
\text { Sorgolactone }\end{array}$ & $\begin{array}{l}\text { Inhibit auxin transport, promote shoot and } \\
\text { root growth and plant defence. }\end{array}$ & [33] \\
\hline Triazoles & Paclobutrazol & $\begin{array}{l}\text { Reduce plant growth, promote flower } \\
\text { development and a greater number of leaves } \\
\text { and roots, and improve tolerance to } \\
\text { environmental or disease stress. } \\
\text { Increase the concentration of chlorophyll } \\
\text { and antioxidant enzymes such as superoxide } \\
\text { dismutase, catalase, ascorbate and } \\
\text { peroxidase. }\end{array}$ & {$[23,26]$} \\
\hline
\end{tabular}

Recent studies report that growth bioregulators, when applied in small concentrations, are easily uptaken and mobilised through the xylem, with the purpose of modifying the physiological behaviour of the plant [4]. There are commercial products that are used as part of the agronomic management of plant growth and development, synthetic analogues of natural bioregulators, including PBZ [25,34]. 


\section{Paclobutrazol (PBZ)}

PBZ was first announced in 1986 as a new bioregulator, which was introduced to the market by ICI Agrochemicals (now part of Syngenta) [5]. It is a synthetic compound [(2 RS, 3 RS) -1- (4-chlorophenyl) - 4,4-dimethyl-2- (1 H-1,2,4-triazol-1-yl) -pentan-3 ol] that inhibits vegetative growth [6,8], belonging to the triazole group [9,11]. Chemical properties of PBZ include: molecular weight 293.8, molecular formula $\mathrm{C}_{15} \mathrm{H}_{20} \mathrm{ClN} 3 \mathrm{O}$, melting point $165^{\circ} \mathrm{C}-166^{\circ} \mathrm{C}$, density $1.22 \mathrm{~g} \mathrm{ml}^{-1}$ and water solubility $35 \mathrm{mg} \mathrm{L}^{-1}$. PBZ is a hydrophobic and slightly polar molecule, with hydrophilic parts [35]. It has two chiral centres (two asymmetric carbons), hence the existence of two pairs of enantiomers [(2R, 3R)- and (2S, 3S)-] and $[(2 \mathrm{~S}, 3 \mathrm{R})-$ and $(2 \mathrm{R}, 3 \mathrm{~S})-]$. However, among the stereoisomers, $2 \mathrm{~S}$ and $3 \mathrm{~S}$ show a higher inhibition efficiency in gibberellin biosynthesis, but $2 \mathrm{R}$ and $3 \mathrm{R}$ are more easily degraded [36].

PBZ is found as an active ingredient in several commercial products such as: "Cultar ${ }^{\circledR} 25 \mathrm{SC}$ " and "Bonzi ${ }^{\circledR}$ " (Syngenta, USA) [5], "Regalis ${ }^{\circledR}$ Plus" (BASF, USA) and "AuStar ${ }^{\circledR}$ " (Chemicals Direct Pty, Ltd., Australia) [16]. It is a non-polar compound with a broad-spectrum nature that is mainly translocated via xylem. However, it will depend on the application route, as it can also be transported via phloem [11,37].

The mode of action of PBZ is framed as part of the terpene pathway. This is, it inhibits the biosynthesis of gibberellins by inactivating the enzyme ent-kaurene oxidase, which catalyses their oxidation to entkaurenoic acid. This favours the activation of the enzymes geranylgeranyl reductase and phytoene synthase for chlorophyll and abscisic acid biosynthesis, respectively (Fig. 1) [23,38,39]. As a result, it decreases vigour and promotes floral induction and development $[9,10,15]$.

Plant growth and development is associated with cell division and expansion induced by gibberellin activity. PBZ applications inhibit its synthesis; consequently, cell elongation does not occur. In the tree you can see a greater number of leaves, shoots and shorter internodes. Likewise, it increases the thickness of the leaves and reduces the size of stomatal pores [40].

\section{Use of PBZ in Fruit Trees}

Among the main effects and physiological processes affected that have been reported with the application of PBZ are the synthesis of gibberellins, floral induction, photosynthetic activity by promoting a higher concentration of chlorophyll, reduction of the transpiration rate (closure of stomata) and activation of antioxidant enzymes (superoxide dismutase, catalase, ascorbate peroxidase and peroxidase) related to the mitigation of oxidative stress [23,37]. It is applied via foliar and soil at concentrations ranging from 1-200 $\mathrm{mg} \mathrm{L}^{-1}$ and $0.1-8.0 \mathrm{mg} \mathrm{L}^{-1}$, respectively [39].

The effect of PBZ has been described, for example, in pear "Clapp's" (Pyrus communis L.). It was applied via foliar at concentrations of 100,200 and $300 \mathrm{mg} \mathrm{L}^{-1}$ during the phenological stage of petal fall, which resulted in a $34 \%$ increase in yield [12]. In India walnut "Ullal-3" (Anacardium occidentale L.) PBZ was applied to the soil for two years at three concentrations (1,2 and $\left.3 \mathrm{~g} \mathrm{~L}^{-1}\right)$, prior to flower opening This resulted in an increase in the number of female flowers and an improvement of 54\% and $30 \%$ in the concentration of chlorophylls a and b, respectively [9].

In China, PBZ is applied to the soil in November and December to reduce the vegetative growth of "Western Schley" pecan [Carya illinoinensis (Wangenh) K. Koch] at concentrations of 30, 90 and $150 \mathrm{mg} \cdot \mathrm{cm}^{2}$ [14]. Another work on olive (Olea europaea L.) "Arbosana" in Tunisia applied PBZ via foliar $\left(10 \mathrm{ml} \mathrm{L}^{-1}\right)$ and edaphic $\left(20 \mathrm{ml} \mathrm{L}^{-1}\right)$, where a significant reduction in shoot length and leaf area was found, but the foliar application was more effective. Additionally, the behaviour of yield indicators (number of inflorescences and number of flowers per inflorescence) was modified with respect to the control [41]. 


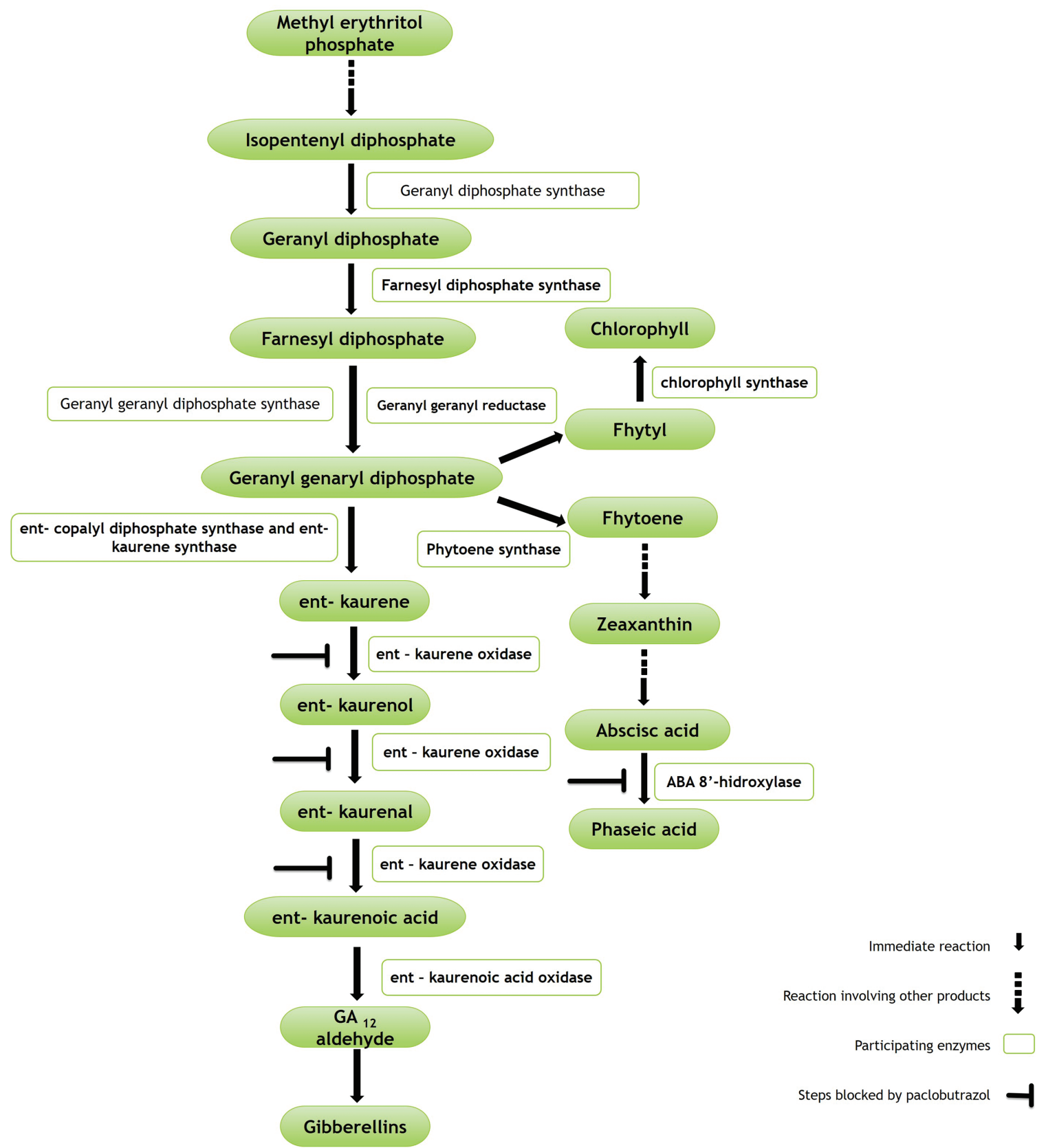

Figure 1: Simplified pathway of terpenes involved in gibberellin biosynthesis, and inhibition sites for abscisic acid and chlorophyll formation. Adapted from [23,38,39]

In order to reduce vegetative growth and promote flowering, PBZ applications are made in July at concentrations of 7.5 and $10 \mathrm{~g} \mathrm{~L}^{-1}$, respectively [42]. In litchi (Litchi chinensis Sonn) "China", soil applications of this product $\left(1,2,3\right.$ and $\left.4 \mathrm{~g} \mathrm{~L}^{-1}\right)$ have been made in September, in which an increase in transpiration rate and stomatal conductance was found. Likewise, the dose of $4 \mathrm{~g} \mathrm{~L}^{-1}$ showed the highest yield, vitamin $\mathrm{C}$ and anthocyanin content in the fruits [11].

Cruz et al. [43] evaluated the effect of PBZ on lime (Citrus latifolia Tanaka) "Tahiti" with a soil application of $800 \mathrm{mg}$ plant $^{-1}$ and found a significant increase in flowering and fruit set. In blackberry 
(Morus alba L.) "S-146", 5, 10, 25, 50, 100 and $500 \mathrm{mg} \mathrm{L}^{-1}$ of PBZ were applied, where an increase in biomass accumulation and the percentage of photochemical efficiency were observed, through the induction of enzymatic antioxidants (superoxide dismutase and catalase) [6].

Authors such as Barman et al. [44] in a research on mango (Mangifera indica L.) "Dashehari" applied $3.2 \mathrm{~mL} \mathrm{~m}^{2}$ of PBZ in the month of September; they reported a significant increase in flowering and $30 \%$ more yield. In another experiment, but with the variety "Namdokmai-sitong", the application was carried out 15 and 45 days after pruning with doses of 500, 1000, 1500 and $2000 \mathrm{mg} \mathrm{L}^{-1}$, which resulted in a decrease in vegetative growth and an improvement in the number of flowers and buds [10]. On the other hand, in Brazil, Do Amaral Brogio et al. [15] carried out foliar applications of PBZ (1750 mg L $\left.\mathrm{m}^{-1}\right)$ on avocado (Persea americana L.) "Hass" and found that it modified the shape of the fruit and caused a significant increase in fruit size.

Foliar application of $2500 \mathrm{mg} \mathrm{L}^{-1} \mathrm{PBZ}$ in the flower bud inductive period (20-25 November) promoted flowering by $40 \%$ and $51 \%$ in orange (Citrus sinensis L. Osb.) "Salustiana" and Citrus $x$ clementina Hort. Ex $\tan$ "Hernandina", respectively [45]. In another study with the orange variety "Navel" grafted on "Carrizo" [Citrus sinensis (L.) Osbeck x Poncirus trifoliata Raf.], but with the soil application of $1000 \mathrm{mg} \mathrm{L}^{-1}$ prior to harvest, a significant improvement was obtained in the colour (color tonality) and carotenoid content of the harvested fruits with respect to the control [46].

As in other countries, PBZ is used in Mexico to promote flowering in mango (Mangifera indica L.) "Ataulfo" as reported by Pérez-Barraza et al. [19]. These authors applied PBZ 30 days after pruning and observed an earlier entry into the flowering period (45 days) with respect to the control. In the "Manila" variety, the same authors when applying $10 \mathrm{~mL}$ of PBZ per tree, found a significant variation by bringing forward flowering by 15 days, and increasing fruit weight and size [18].

In guava (Psidium guajaba L.) "Calvillo" it was applied at concentrations of $1 \mathrm{~mL}^{-1} \mathrm{tree}^{-1}$ and $2 \mathrm{~mL}$ tree ${ }^{-1}$ at the base of the stem after pruning. This affected vegetative growth with a reduction of between $15 \%$ and $41 \%$, and an increase in fruit number of $30 \%$ [16]. The dose, effect and type of application (edaphic and foliar) of PBZ on various fruit trees are described in Tab. 2.

Table 2: Doses and effects of PBZ applied to various fruit trees

\begin{tabular}{|c|c|c|c|c|}
\hline Fruit-tree & $\begin{array}{l}\text { Form of } \\
\text { application }\end{array}$ & Dose & Effect & Source \\
\hline $\begin{array}{l}\text { Anacardium } \\
\text { occidentale L. }\end{array}$ & Edaphic & 300 & $\begin{array}{l}\text { Reduced vegetative growth. } \\
\text { Flowering increased by } 30 \% \\
\text { Increased female flower production by } 45 \% \text { to } 54 \% \text {. } \\
\text { Increased chlorophyll a and b concentrations by } 54 \% \text { and } 30 \% \text {, } \\
\text { respectively. }\end{array}$ & [9] \\
\hline $\begin{array}{l}\text { Litchi chinenesis } \\
\text { Sonn }\end{array}$ & Edaphic & $\begin{array}{l}100 \\
200 \\
300 \\
400\end{array}$ & $\begin{array}{l}\text { Increase the concentrations of chlorophyll a and } b \text {. } \\
\text { Reduced leaf nitrogen content (1.5\%). } \\
\text { The high dose increased yield by } 60 \% \text {. }\end{array}$ & {$[11]$} \\
\hline \multirow[t]{2}{*}{$\begin{array}{l}\text { Carya illinoinensis } \\
\text { (Wangenh) K. Koch }\end{array}$} & Edaphic & $\begin{array}{l}300 \\
900 \\
1500\end{array}$ & $\begin{array}{l}\text { Annual delay in terminal shoot growth relative to the control. } \\
\text { Increased short shoot production by } 60 \% \text {, with a reduction in } \\
\text { long shoots for all doses relative to the control. } \\
\text { Increased flowering by } 35 \% \text { at the lower dose rate. }\end{array}$ & [14] \\
\hline & & 1250 & Inhibited vegetative growth (reduced shoot length). & {$[13]$} \\
\hline
\end{tabular}




\begin{tabular}{|c|c|c|c|c|}
\hline Fruit-tree & $\begin{array}{l}\text { Form of } \\
\text { application }\end{array}$ & Dose & Effect & Source \\
\hline Mangifera indica $\mathrm{L}$. & Edaphic & $\begin{array}{l}750 \\
1000\end{array}$ & $\begin{array}{l}\text { Reduced shoot growth by } 30 \% \text { and } 13 \% \text {, respectively. } \\
\text { Modified flowering date by an average of } 45 \text { days compared to } \\
\text { the control. } \\
\text { Both doses increased the number of panicles. } \\
\text { Significantly increased yield. } \\
\text { Increased yield eight times more than the control at both doses. } \\
\text { Improved fruit quality at both doses. }\end{array}$ & {$[42]$} \\
\hline \multirow[t]{2}{*}{ Mangifera indica $\mathrm{L}$. } & Edaphic & $\begin{array}{l}700 \\
1000 \\
1300 \\
1600 \\
1900\end{array}$ & $\begin{array}{l}\text { The lower doses increased gas exchange by } 23 \% \text { compared to } \\
\text { the higher doses. } \\
\text { Increasing doses of paclobutrazol resulted in a } 31 \% \text { decrease in } \\
\text { sugars } \\
31 \% \text { decrease in total soluble sugars, } 54 \% \text { decrease in reducing } \\
\text { sugars and } 29 \% \text { decrease in non-reducing sugars. }\end{array}$ & {$[47]$} \\
\hline & Foliar & $\begin{array}{l}320 \\
2500 \\
1000\end{array}$ & $\begin{array}{l}25 \% \text { increase in flowering. } \\
60 \% \text { increase in flowering and bud differentiation. } \\
80 \% \text { increased flowering and significantly decreased shoot } \\
\text { length. }\end{array}$ & {$[44]$} \\
\hline Olea europaea L. & Edaphic & $\begin{array}{l}10 \\
20\end{array}$ & Application inhibited growth by $55 \%$ and $82 \%$ for each dose. & {$[41]$} \\
\hline Morus alba L. & Edaphic & $\begin{array}{l}5 \\
10 \\
25 \\
50 \\
100 \\
500\end{array}$ & $\begin{array}{l}\text { Increased biomass accumulation (leaves) and net photosynthetic } \\
\text { rate }(38 \%) \text {. }\end{array}$ & {$[6]$} \\
\hline Psidium guajava L. & Edaphic & $\begin{array}{l}100 \\
200\end{array}$ & $\begin{array}{l}\text { Growth rate decreased by } 15 \% \text { to } 41 \% \text { compared to the control. } \\
\text { Increase of } 30 \% \text { and } 37 \% \text { in yield and number of fruits, } \\
\text { respectively. }\end{array}$ & {$[16]$} \\
\hline $\begin{array}{l}\text { Persea americana } \\
\text { Mill. }\end{array}$ & Foliar & 1750 & $\begin{array}{l}\text { Increased fruit length, diameter and weight by } 11 \%, 5.3 \% \text { and } \\
1.5 \% \text {, respectively, with respect to the control. }\end{array}$ & {$[15]$} \\
\hline Pyrus communis L. & Foliar & 200 & $\begin{array}{l}\text { Inhibited vegetative growth. } \\
\text { Increased fruit quality (total soluble solids, total sugars and } \\
\text { juice) and yield. }\end{array}$ & {$[12]$} \\
\hline Vitis vinifera $\mathrm{L}$. & Foliar & $\begin{array}{l}200 \\
300\end{array}$ & $\begin{array}{l}\text { Increased bunch weight by } 54 \%(107.41 \mathrm{~g}) \text { compared to the } \\
\text { control }(69.84 \mathrm{~g}) \text { as well as an increase in yield by } 64 \% \text {. } \\
\text { Increased chlorophyll content by } 31.5 \% \text { and reduced shoot } \\
\text { length by } 33.8 \% \text {. }\end{array}$ & [48] \\
\hline $\begin{array}{l}\text { Myrica rubra Sieb. et } \\
\text { Zucc. }\end{array}$ & Foliar & $\begin{array}{l}100 \\
200\end{array}$ & $\begin{array}{l}\text { Increased fruit weight by } 50 \% \text {. } \\
\text { Increased fruit weight by } 30.5 \% \text {, increased soluble solids } \\
\text { concentrations by } 13 \% \text { and decreased total acidity by } 38 \% \text {. }\end{array}$ & [49] \\
\hline
\end{tabular}


PBZ can be a tool to increase yields in fruit crops such as pear, litchi, mango, if it is applied in adequate concentrations and at the appropriate phenological stages. However, it is necessary to know the physiological processes of the species which are implied in the final response, and what is intended to be modified. This is because it can have an impact on improving the yield and quality of the harvested product (Fig. 2) [23,39,41].

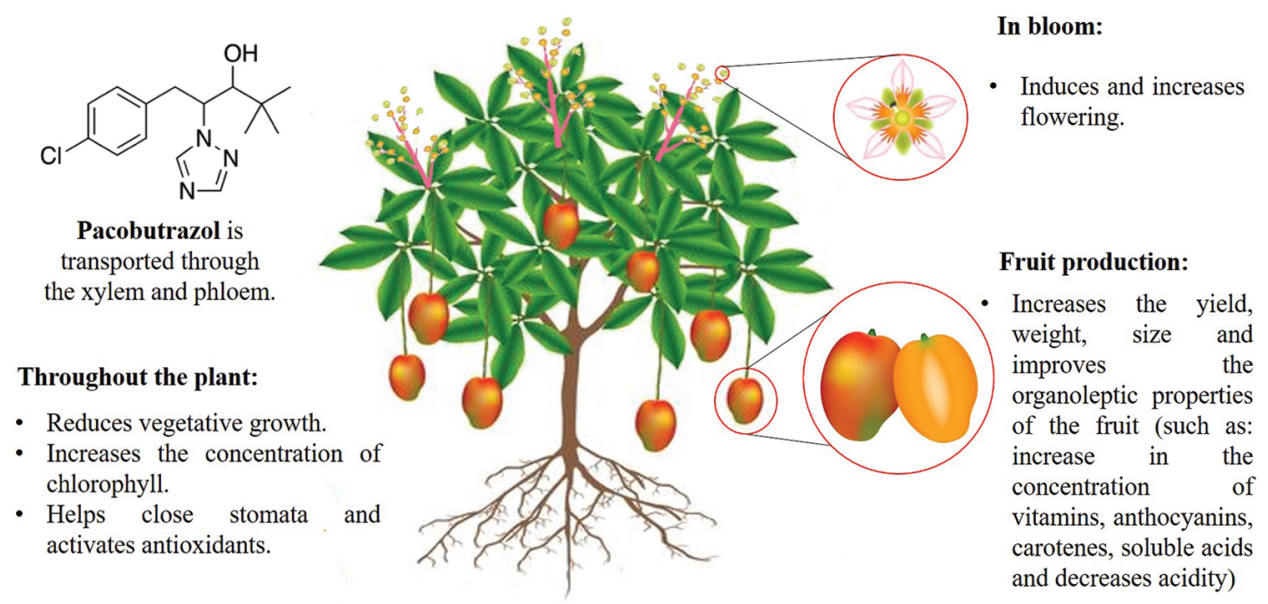

Figure 2: Summary of main key mechanisms that paclobutrazol targets in fruit trees

\section{Effects of PBZ on the Environment}

Recent studies have demonstrated that the residual nature of PBZ affects soil microbial life (reduction in the number of fungi, bacteria, actinomycetes and earthworms), which impairs plant growth and development [21]. In addition, leaching and contamination of aquifers can occur [8,17]. On the other hand, the behaviour of PBZ in soil has a residual effect of 450 to 950 days and can be maintained at a depth of 60 to $120 \mathrm{~cm}$ [37]. Other authors reported that PBZ has an easy uptake by the crop roots, and can have a persistence in soil from 43 to 618 days, with concentrations ranging from 1.1 to $50 \mathrm{mg} \mathrm{kg}^{-1}$. Another important effect is the inhibition of root growth and development of plantations in soils with previous PBZ applications [35]. On the other hand, in mango, Lin et al. [50] report a reduction in the density of beneficial soil microorganisms, in particular the number of bacteria, fungi and actinomycetes by $58 \%, 28 \%$ and $28 \%$, respectively, when evaluating PBZ applications.

The life of PBZ in water is shorter (i.e., no longer than 3 weeks), but it can cause potential damage to the flora and fauna [37]. The presence of PBZ in water can cause various physiological effects in fish (survival rate, embryonic hatching, failure in the development of the skeleton of the head and eyes) [21,51]. Such is the case of Daphnia magna (water flea) which showed physical deformities when exposed to $240 \mu \mathrm{g} \mathrm{L}^{-1}$ of PBZ in the embryonic stage [39]. When evaluating the survival and deleterious effect of $\operatorname{PBZ}(0.34,3,4,17 \mu \mathrm{m})$ applied to zebrafish (Danio rerio) embryos at 24, 36, 48, 60, 72 and 96 hours after fertilisation, Wang et al. [21] report the development of pericardial oedema, cardiovascular dysfunction and skeletal malformations. Osuna-García et al. [17] found traces of PBZ in fruit samples when applying doses of 5 and $2.5 \mathrm{~mL}$ of PBZ per tree to "Tommy Atkins" mango; however, the authors indicate that these concentrations are not harmful to human health. In some countries it is prohibited and/or restricted the use of PBZ due to the residual effects on fruits that can be harmful to human health (Tab. 3) [35].

PBZ residues can affect human health through direct contact, inhalation, contamination of water bodies, consumption of contaminated fish and fruits containing residues [37]. Adverse health effects can occur after years of minimal exposure in the environment, food and water [52]. There are few studies on the harmful effects caused to human health by ingestion or contact with PBZ (Fig. 3) [53]. Experiments have been 
carried out on pregnant rats were fed with doses of $1.0 \mathrm{mg} \mathrm{kg}^{-1} \mathrm{PBZ}$ and the results have been extrapolated to humans: no reproductive effects were observed, but malformations (cleft palate) were determined. These malformations were attributed to a toxic effect of PBZ. Further studies were recommended to determine whether PBZ is the cause of this effect [54,55].

Table 3: Maximum residue limit in fruits for paclobutrazol in some countries

\begin{tabular}{|c|c|c|c|c|c|c|c|}
\hline Countries & China & Japan & European Union & South Korea & Australia & USA & Sweden \\
\hline $\begin{array}{l}\text { LMR } \\
\left(\mathrm{mg} \mathrm{kg}^{-1}\right)\end{array}$ & 0.5 & 0.01 & 0.01 & 0.01 & 0.01 & Ornamental & Forbidden \\
\hline
\end{tabular}

Note: LMR-maximum residue limit.

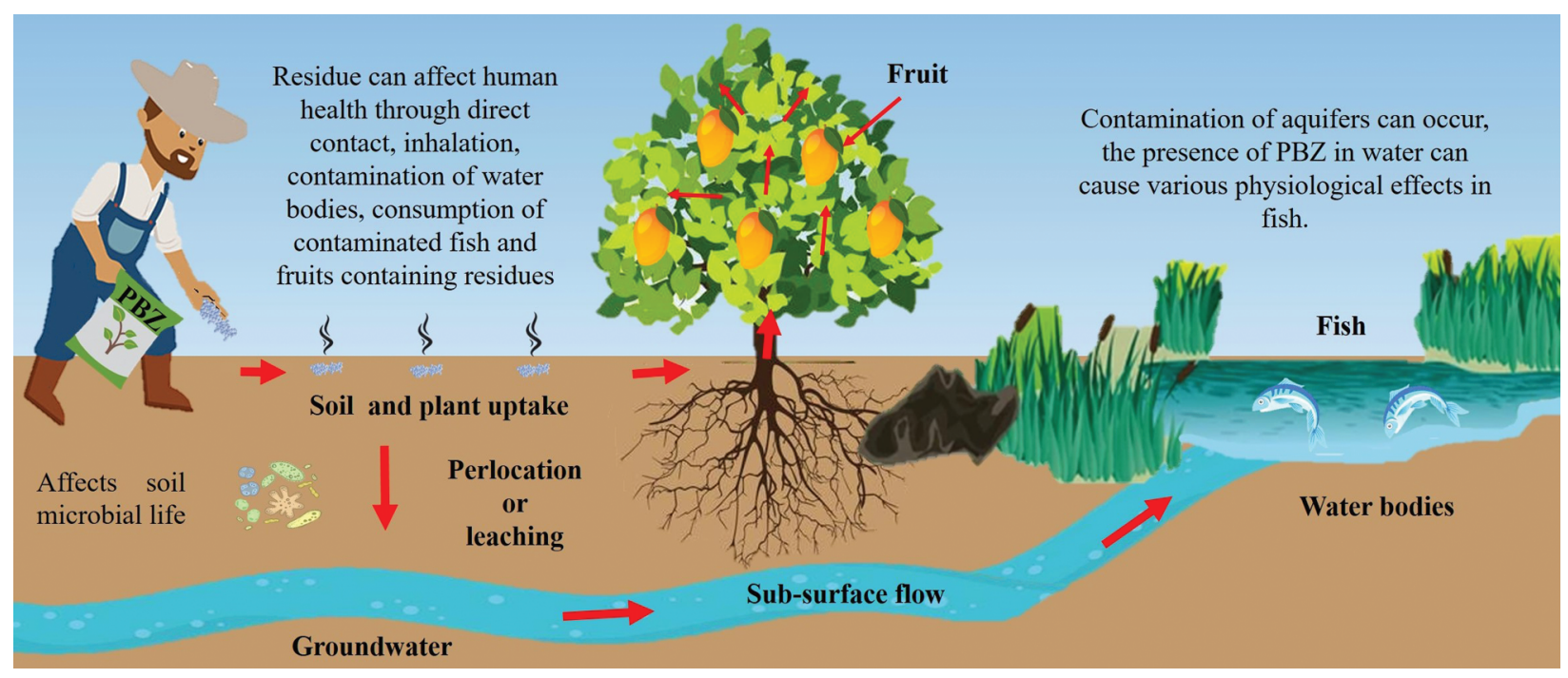

Figure 3: Effect of paclobutrazol on living beings

\section{Future Perspectives}

Paclobutrazol is a growth inhibitor and also belongs to the triazol group. The use of this product on fruit trees (mango, lime, apple and guava) inhibits the biosynthesis of gibberellins; cell division occurs, cell elongation and expansion do not occur. This allows a greater production of shoots, number of leaves and internodes, but they will be shorter. PBZ induces flowering with a consequent increase in fruit yield, weight, size, and it improves the organoleptic properties of fruit.

On the other hand, in some countries it is prohibited and/or restricted by the documentary evidence of its residual and harmful effects on the environment (soil and groundwater) and human health (LMR in fruits). However, fruit production is associated with an extensive use of PBZ in Latin America. There is little evidence of a legal framework that allows users to implement the optimal use of this product, to mitigate possible effects on the environment and human health. For this reason, the agronomic management of PBZ must have protocols that seek its regulation with a rational and sustainable approach.

Funding Statement: The authors did not receive specific funding for this study.

Conflicts of Interest: The authors declare that they have no conflict of interest to report in this paper. 


\section{References}

1. Altieri, M. A., Funes-Monzote, F. R., Petersen, P. (2012). Agroecologically efficient agricultural systems for smallholder farmers: Contributions to food sovereignty. Agronomy for Sustainable Development, 32(1), 1-13. DOI 10.1007/s13593-011-0065-6.

2. Diaz, D. A. V., Pérez, L. S., Rangel, P. P., Castruita, M. Á. S., Fuentes, J. A. G. et al. (2016). Effect of salicylic acid on the production and nutraceutical quality of tomato fruits. Revista Mexicana de Ciencias Agrícolas, 17(8), 34053414. https://www.redalyc.org/articulo.oa?id=263149506002.

3. Urquía-Fernández, N. (2014). La seguridad alimentaria en México. Salud pública de México, 56(Supl. 1), s92-s98. http://www.scielo.org.mx/pdf/spm/v56s1/v56s1a14.pdf.

4. Martínez-Damián, M. T., Cano-Hernández, R., Moreno-Pérez, E. C., Sánchez-del Castillo, F., Cruz-Álvarez, O. (2019). Effect of preharvest growth bioregulators on the physicochemical quality of saladette tomato. Revista Chapingo Serie Horticultura, 25(1), 29-43. DOI 10.5154/r.rchsh.2018.06.013.

5. Rademacher, W. (2016). Chemical regulators of gibberellin status and their application in plant production. Annual Plant Reviews Online, 49, 359-403. DOI 10.1002/9781119210436.

6. Mohan, R., Kaur, T., Bhat, H. A., Khajuria, M., Pal, S. et al. (2019). Paclobutrazol induces photochemical efficiency in mulberry (Morus alba L.) under water stress and affects leaf yield without influencing biotic interactions. Journal of Plant Growth Regulation, 39(1), 1-11. DOI 10.1007/s00344-019-09975-0.

7. Rademacher, W. (2015). Plant growth regulators: Backgrounds and uses in plant production. Journal of Plant Growth Regulation, 34(4), 845-872. DOI 10.1007/s00344-015-9541-6.

8. Zhang, L., Luo, Z., Cui, S., Xie, L., Yu, J. et al. (2019). Residue of paclobutrazol and its regulatory effects on the secondary metabolites of Ophiopogon japonicas. Molecules, 24(19), 3504. DOI 10.3390/molecules24193504.

9. Mog, B., Janani, P., Nayak, M., Adiga, J., Meena, R. (2019). Manipulation of vegetative growth and improvement of yield potential of cashew (Anacardium occidentale L.) by paclobutrazol. Scientia Horticulturae, 257(2), 108748. DOI 10.1016/j.scienta.2019.108748.

10. Wongsrisakulkaew, Y., Boonprakob, U., Sethpakdee, R., Juntawong, N. (2017). Effect of paclobutrazol concentrations and time of foliar application on flowering of 'Namdokmai-Sitong' mango. International Journal of GEOMATE, 12(30), 41-45. DOI 10.21660/2017.30.96545.

11. Singh, S. K., Pandey, A. K., Singh, P. (2019). Gaseous exchange, biochemical parameters and yield as affected by application techniques and doses of paclobutrazol in litchi tree. Indian Journal of Horticulture, 76(2), 265-272. DOI 10.5958/0974-0112.2019.00041.0.

12. Lal, M., Mir, M., Iqbal, U., Kumar, A. (2018). Response of prohexadione calcium and paclobutrazol on growth and physio-chemical characteristics of pear cv. Clapp's favorite. Indian Journal of Horticulture, 75(2), 191-196. DOI 10.5958/0974-0112.2018.00035.X.

13. Luo, X., Li, Z., Sun, Z., Wan, X. (2016). Analysis of pecan cultivars Mahan and Western in East China. Genetics and Molecular Research, 15(3). DOI 10.4238/gmr.15038732.

14. Zhu, H., Stafne, E. T. (2019). Influence of paclobutrazol on shoot growth and flowering in a high-density pecan orchard. HortTechnology, 29(2), 210-212. DOI 10.21273/HORTTECH04241-18.

15. Do Amaral Brogio, B., da Silva, S. R., Cantuarias-Avilés, T., Angolini, S. F., Baptista, E. G. et al. (2018). Influence of gibberellin inhibitors on the flowering of non-irrigated 'Hass' avocados. Pesquisa Agropecuária Brasileira, 53(8), 918-923. DOI 10.1590/s0100-204x2018000800006.

16. Padilla-Ramírez, J. S., Rodríguez-Moreno, V. M., González-Gaona, E., Osuna-Ceja, E. S., Pérez-Barraza, M. H. (2017). Influence of paclobutrazol on shoot growth and yield of Psidum guajava L. in high density. Revista Mexicana de Ciencias Agrícolas, 8(19), 3965-3977. DOI 10.29312/remexca.v0i19.666.

17. Osuna-García, J. A., Báez-Sañudo, R., Medina-Urrutia, V. M., Chávez-Contreras, X. (2001). Paclobutrazol residues in 'Tommy Atkins' mango fruits (Mangifera indica L.). Revista Chapingo Serie Horticultura, 7(2), 275-282. DOI 10.5154/r.rchsh.2000.10.069.

18. Pérez-Barraza, M. H., Osuna-García, J. A., Sánchez-Lucio, R., Vázquez-Valdivia, V. (2011). Paclobutrazol ensures abundant and advanced flowering in 'Manila' mango, even without environmental conditions. Revista Chapingo Serie horticultura, 17(4), 47-52. DOI 10.5154/r.rchsh.2011.17.037. 
19. Pérez-Barraza, M. H., Avitia-García, E., Cano-Medrano, R., Gutiérrez-Espinosa, M. A., Osuna-Enciso, T. et al. (2018). Temperature and gibberelin inhibitors in the flowering process of mango cv. 'Ataulfo'. Revista Fitotecnia Mexicana, 41(4A), 543-549. https://www.revistafitotecniamexicana.org/41-4A.html.

20. Zou, N., Yuan, C., Chen, R., Yang, J., Li, Y. et al. (2016). Study on mobility, distribution and rapid ion mobility spectrometry detection of seven pesticide residues in cucumber, apple, and cherry tomato. Journal of Agricultural and Food Chemistry, 65(1), 182-189. DOI 10.1021/acs.jafc.6b03084.

21. Wang, W. D., Wu, C. Y., Lonameo, B. K. (2019). Toxic effects of paclobutrazol on developing organs at different exposure times in zebrafish. Toxics, 7(4), 62. DOI 10.3390/toxics7040062.

22. Mirzajani, R., Ramezani, Z., Kardani, F. (2017). Selective determination of thidiazuron herbicide in fruit and vegetable samples using molecularly imprinted polymer fiber solid phase microextraction with ion mobility spectrometry detection (MIPF-SPME-IMS). Microchemical Journal, 130, 93-101. DOI 10.1016/j. microc.2016.08.009.

23. Soumya, P., Kumar, P., Pal, M. (2017). Paclobutrazol: A novel plant growth regulator and multi-stress ameliorant. Indian Journal of Plant Physiology, 22(3), 267-278. DOI 10.1007/s40502-017-0316-x.

24. Chávez-Suárez, L., Álvarez-Fonseca, A., Ramírez-Fernández, R. (2012). Notes of the influence of some plant growth regulators in the abiotic stress plant response. Cultivos Tropicales, 33(3), 47-56. http://ediciones.inca. edu.cu/index.php/ediciones/issue/view/48.

25. Pai, S. R., Desai, N. S. (2018). Effect of TDZ on various plant cultures. Thidiazuron: From urea derivative to plant growth regulator, pp. 439-454. Singapore: Springer, DOI 10.1007/978-981-10-8004-3_25.

26. Fahad, S., Hussain, S., Matloob, A., Khan, F. A., Khaliq, A. et al. (2015). Phytohormones and plant responses to salinity stress: A review. Plant Growth Regulation, 75(2), 391-404. DOI 10.1007/s10725-014-0013-y.

27. Luna-Esquivel, E. N., Ojeda-Barrios, D. L., Guerrero-Prieto, V. M., Ruiz-Anchondo, T., Martínez-Téllez, J. J. (2014). Polyamines as indicators of stress in plants. Revista Chapingo Serie Horticultura, 20(3), 283-295. DOI 10.5154/r.rchsh.2013.05.019.

28. Luo, Z., Zhang, L., Mou, Y., Cui, S., Gu, Z. et al. (2019). Multi-residue analysis of plant growth regulators and pesticides in traditional Chinese medicines by high-performance liquid chromatography coupled with tandem mass spectrometry. Analytical and Bioanalytical Chemistry, 411(11), 2447-2460. DOI 10.1007/s00216-019-01691-8.

29. Mesejo, C., Yuste, R., Reig, C., Martínez-Fuentes, A., Iglesias, D. J. et al. (2016). Gibberellin reactivates and maintains ovary-wall cell division causing fruit set in parthenocarpic Citrus species. Plant Science, 247, 13-24. DOI 10.1016/j.plantsci.2016.02.018.

30. Tesfahun, W. (2018). A review on: Response of crops to paclobutrazol application. Cogent Food \& Agriculture, 4(1), 1525169. DOI 10.1080/23311932.2018.1525169.

31. Nisler, J. (2018). TDZ: Mode of action, use and potential in agriculture. Thidiazuron: From urea derivative to plant growth regulator, pp. 37-59. Singapore: Springer, DOI 10.1007/978-981-10-8004-3_2.

32. Hernández-Silva, E., García-Martínez, I. (2016). Brassinosteroids in agricultura I. Revista Mexicana de Ciencias Agrícolas, 7(2), 441-450. DOI 10.29312/remexca.v7i2.356.

33. Waters, M. T., Gutjahr, C., Bennett, T., Nelson, D. C. (2017). Strigolactone signaling and evolution. Annual Review of Plant Biology, 68(1), 291-322. DOI 10.1146/annurev-arplant-042916-040925.

34. Koprna, R., De Diego, N., Dundálková, L., Spíchal, L. (2016). Use of cytokinins as agrochemicals. Bioorganic \& Medicinal Chemistry, 24(3), 484-492. DOI 10.1016/j.bmc.2015.12.022.

35. Jiang, X., Wang, Y., Xie, H., Li, R., Wei, J. et al. (2019). Environmental behavior of paclobutrazol in soil and its toxicity on potato and taro plants. Environmental Science and Pollution Research, 26(26), 27385-27395. DOI 10.1007/s11356-019-05947-9.

36. Wu, S., Yu, M., Zhang, H., Han, J., Qian, M. (2015). Enantioselective degradation of (2RS, 3RS)-8. paclobutrazol in rat liver microsomes. Chirality, 27(5), 344-348. DOI 10.1002/chir.22440.

37. Kishore, K., Singh, H., Kurian, R. (2015). Paclobutrazol use in perennial fruit crops and its residual effects: A review. Indian Journal of Agricultural Sciences, 85(7), 863-872. http://epubs.icar.org.in/ejournal/index.php/ $\underline{\mathrm{IJAgS} / \text { article/view/50091. }}$. 
38. Hedden, P., Sponsel, V. (2015). A century of gibberellin research. Journal of Plant Growth Regulation, 34(4), 740760. DOI 10.1007/s00344-015-9546-1.

39. Grant, G. A., Fisher, P. R., Barrett, J. E., Wilson, P. C. (2018). Removal of paclobutrazol from irrigation water using granular-activated carbon. Irrigation Science, 36(3), 159-166. DOI 10.1007/s00271-018-0572-1.

40. Kumar, A., Ram, S., Bist, L. D., Singh, C. P. (2021). Paclobutrazol boost up for fruit production: A review. Annals of the Romanian Society for Cell Biology, 25(6), 963-980. https://www.annalsofrscb.ro/index.php/journal/article/ view/5582.

41. Ajmi, A., Larbi, A., Morales, M., Fenollosa, E., Chaari, A. et al. (2020). Foliar paclobutrazol application suppresses olive tree growth while promoting fruit set. Journal of Plant Growth Regulation, 39(4), 1-9. DOI 10.1007/s00344-020-10188-z.

42. Sarker, B., Rahim, M., Archbold, D. (2016). Combined effects of fertilizer, irrigation, and paclobutrazol on yield and fruit quality of mango. Horticulturae, 2(4), 14. DOI 10.3390/horticulturae2040014.

43. Cruz, M. D. C. M. D., Siqueira, D. L. D., Salomão, L. C. C., Cecon, P. R. (2008). Influence of paclobutrazol and of the environment temperature on flowering and fruitification of acid lime Tahiti. Ciência e Agrotecnologia, 32(4), 1148-1153. DOI 0.1590/S1413-70542008000400017.

44. Barman, P., Mishra, D. (2018). Tip pruning for synchronized vegetative growth and controlling alternate bearing in mango (Mangifera indica L.). Indian Journal of Agricultural Sciences, 88(4), 621-627. http://epubs.icar.org.in/ ejournal/index.php/IJAgS/article/view/79137.

45. Martínez-Fuentes, A., Mesejo, C., Muñoz-Fambuena, N., Reig, C., González-Mas, M. C. et al. (2013). Fruit load restricts the flowering promotion effect of paclobutrazol in alternate bearing Citrus spp. Scientia Horticulturae, 151, 122-127. DOI 10.1016/j.scienta.2012.12.014.

46. Rehman, M., Singh, Z., Khurshid, T. (2018). Pre-harvest spray application of prohexadione-calcium and paclobutrazol improves rind colour and regulates fruit quality in M7 Navel oranges. Scientia Horticulturae, 234(2), 87-94. DOI 10.1016/j.scienta.2018.02.018.

47. Souza, M. A., Mésquita, A. C., Simões, W. L., Ferreira, K. M., Araujo, E. F. J. (2016). Physiological and biochemical characterization of mango tree with paclobutrazol application via irrigation. Pesquisa Agropecuária Tropical, 46(4), 442-449. DOI 10.1590/1983-40632016v4642829.

48. Baninasab, B., Shahgholi, M. (2012). Effect of paclobutrazol on vegetative growth, yield and fruit quality of Keshmeshi Bovanat grape. Acta Horticulturae, 931, 449-452. DOI 10.17660/ActaHortic.2012.931.53.

49. Meng, C. F., Jiang, P. K., Cao, Z. H., Zhou, G. M., Xu, Q. F. (2012). Effects of boron and paclobutrazol on growth, fruit set, nutrient uptake, and alternate bearing of Muye red bayberry. Communications in Soil Science and Plant Analysis, 43(16), 2114-2125. DOI 10.1080/00103624.2012.697233.

50. Lin, C. H., Kuo, J., Wang, Y. W., Chen, M., Lin, C. H. (2010). Bacterial diversity in paclobutrazol applied agricultural soils. Journal of Environmental Science and Health Part B, 45(7), 710-717. DOI 10.1080/ 03601234.2010.502464.

51. Wang, W. D., Chen, G. T., Hsu, H. J., Wu, C. Y. (2015). Aryl hydrocarbon receptor 2 mediates the toxicity of Paclobutrazol on the digestive system of zebrafish embryos. Aquatic Toxicology, 159, 13-22. DOI 10.1016/j. aquatox.2014.11.018.

52. Lozowicka, B. (2015). Health risk for children and adults consuming apples with pesticide residue. Science of the Total Environment, 502(1), 184-198. DOI 10.1016/j.scitotenv.2014.09.026.

53. Burns, C. J., McIntosh, L. J., Mink, P. J., Jurek, A. M., Li, A. A. (2013). Pesticide exposure and neurodevelopmental outcomes: Review of the epidemiologic and animal studies. Journal of Toxicology and Environmental Health, Part B, 16(3-4), 127-283. DOI 10.1080/10937404.2013.783383.

54. European Food Safety Authority (EFSA) (2010). Conclusion on the peer review of the pesticide risk assessment of the active substance paclobutrazol. EFSA Journal, 8(11), 1876. DOI 10.2903/j.efsa.2010.1876.

55. Ramírez-Bustos, I. I., López-Martínez, V., Juarez-Lopez, P., Alía-Tejacal, I., Guillén-Sánchez, D. et al. (2018). Monitoring of pesticides in the cultivation of nopal vegetable [Opuntia ficus-indica (L.) Mill], Morelos, México. Agriculture, 8(11), 174. DOI 10.3390/agriculture8110174. 